\title{
ORIGIN OF DIAMONDIFEROUS ARCHEAN LAMPROPHYRES IN THE EVOLUTION OF THE MICHIPICOTEN AND ABITIBI GREENSTONE BELTS
}

\author{
J.A. Ayer ${ }^{1}$ and D. A. Wyman ${ }^{2}$ \\ ${ }^{1}$ Ontario Geological Survey, Sudbury, Canada $;{ }^{2}$ University of Sydney, Sydney, Australia
}

\section{INTRODUCTION}

Diamonds have recently been discovered in Archeanaged lamprophyres and associated heterolithic breccias in the Michipicoten greenstone belt (MGB), in the Wawa area, and within the Abitibi greenstone belt (AGB), in the Cobalt area (Figure 1). An age of $2674 \pm 8$ Ma for titanite (Sage, unpublished data) in a diamondiferous lamprophyre dike at the GQ discovery site in Musquash Township in the Wawa area is similar to $2674 \mathrm{Ma} \pm 2$ Ma for titanites from non-diamondiferous lamprophyre dikes in the Kirkland Lake area (Wyman and Kerrich 1993). At $2.67 \mathrm{Ga}$, the lamprophres are the oldest known primary source of diamonds and represent the first confirmed occurrence in calc-alkalic lamprophyres. The occurrence of diamonds in these Archean rocks is however somewhat problematic in that their chemical compositions indicates derivation by partial melting of spinel lherzolite at mantle depth of less than $80 \mathrm{~km}$, whereas typically the diamond stability field occurs at depths in excess of $150 \mathrm{~km}$.

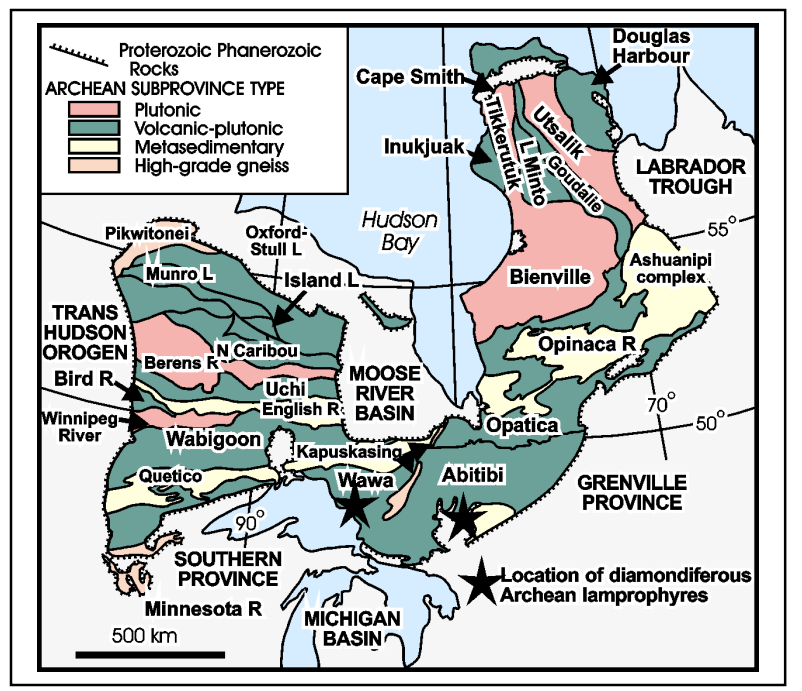

Figure 1: The Superior Province with its subprovinces and the location of known diamondiferous lamprophyre clusters.
Recent mapping and U-Pb geochronology in the southern AGB (Ayer et al. 2002a) has revealed that from 2750 to $2700 \mathrm{Ma}$, a predominantly volcanic stratigraphy developed that was up to $20 \mathrm{~km}$ thick (Figure 2). The presence of abundant inherited zircons with similar ages to those found in underlying assemblages shows that the volcanic stratigraphy developed autochthonously rather than by allochthonous accretion in a collisional arc environment (c.f., Jackson et al. 1994). The volcanic assemblages show varying degrees of intermingling of magmas of komatiitic, tholeiitic and calc-alkalic affinities indicating two distinctive mantle sources, one with large degrees of partial melting, probably associated with mantle plumes, and the other, small degrees of partial melting of an LILE-enriched mantle wedge. Both of these sources had similarly depleted $\mathrm{Nd}$ isotopic signatures suggesting they evolved in an ensimatic, possibly a "back-arc"-like, geodynamic environment without evidence of contamination by ancient continental crust (i.e. $>2.9 \mathrm{Ga}$ ).

The timing and nature of the supracrustal units in the MGB (Sage et al. 1996) are distinctive from that of the AGB. Four cycles have an estimated total thickness of 10-15 km (Figure 2). The lowermost cycle has an age ca. $2890 \mathrm{Ma}$ and consists of komatiites and $\mathrm{Mg}$ tholeiites, overlain by calc-alkalic felsic volcanic rocks, capped by iron formation. Cycle 2 ranges in age from 2750 to 2730 $\mathrm{Ma}$ and consists of $\mathrm{Mg}$ and $\mathrm{Fe}$ tholeiites succeeded by calc-alkalic felsic volcanic rocks, capped by iron formation. It is similar in age and composition to the two lowermost assemblages (Pacaud and Deloro) in the AGB. Cycle 3 ranges from ca. 2710 to $2700 \mathrm{Ma}$ and consists of tholeiitic basalts overlain by felsic volcanic rocks and iron formation. The ${ }^{207} \mathrm{~Pb} /{ }^{206} \mathrm{~Pb}$ ratios of the basalts and $2670 \mathrm{Ma}$ intrusions are significantly more evolved than typical depleted values from the southern Superior Province and suggest contamination by an older crustal reservoirs (Corfu and Sage 1992). Based on geochemical patterns Sage et al. (1996) interpreted that the mafic to ultramafic volcanic rocks were derived from athenospheric mantle with assimilation of older continental crust, and the felsic volcanic rocks represented moderate to high degrees of partial melts of tonalitic upper crust, both of which are interpreted analogous to Phanerozoic flood basalt sequences such as the Ontong-Java.

\section{GREENSTONE BELT EVOLUTION}




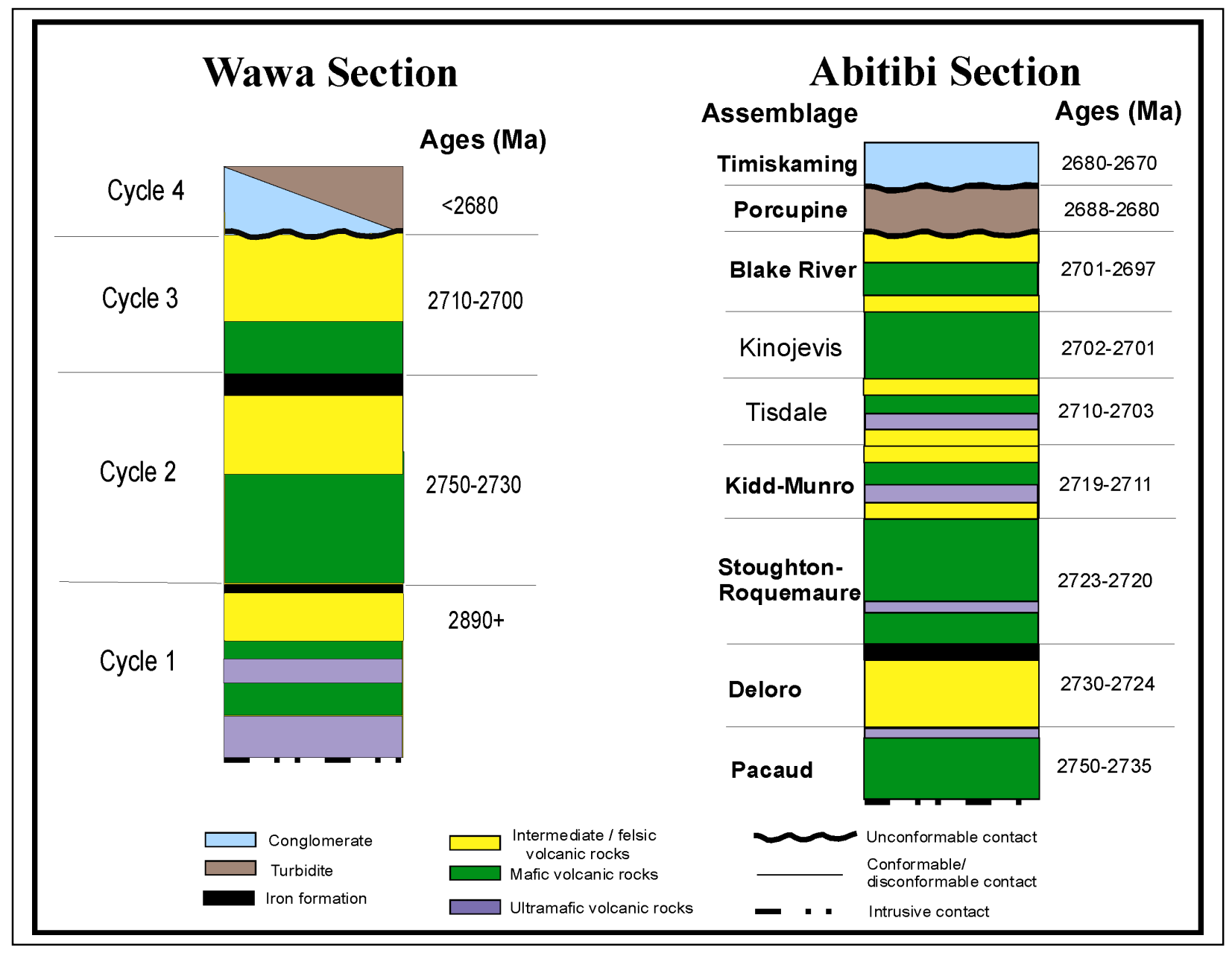

Figure 2: Idealized stratigraphic sections and ages of the MGB and AGB.

Both The AGB and MGB have synvolcanic TTG intrusions which are similar in age and compositions to their felsic volcanic rocks. Syn- to post- tectonic intrusions range in age from 2700 to $2670 \mathrm{Ma}$ and are typically more potassic. Calc-alkalic lamprophyre dikes were emplaced ca $2670 \mathrm{Ma}$ and occur as part of a mildy alkalic igneous suite associated with late-tectonic syenites.

Two unconformity bound sedimentary sequences occur in the upper part of the AGB stratigraphic succession (Ayer et al. 2002b). The earlier sequence is identified as the Porcupine assemblage and ranges in age from 2688 Ma to $2680 \mathrm{Ma}$. It consists of turbidites with local intercalations of felsic volcanics and iron formations deposited in a submarine environment. The Timiskaming assemblage ranges in age from ca. 2680 to $2670 \mathrm{Ma}$ and consist of conglomerate, sandstone and alkalic volcanics (similar in age and composition to the syenite intrusions) deposited in alluvial-fan, fluvial and deltaic environments. In the MGB, the clastic sedimentary units do not have as well constrained ages. They are grouped together into cycle 4 (Fig. 2) with detrital zircons indicating maximum depositional ages ranging from 2698 to $2680 \mathrm{Ma}$. They consist of coarse conglomerate and wacke grading to finer-grained wacke and shale in the east and are interpreted to represent subaerial alluvial fan or fan-delta environments as well as deep sea fan deposits (Corfu and Sage 1992). Three compressional events occurred from ca. 2685 to post-2670 Ma in the AGB (Ayer et al. 2002b), followed by peak metamorphic ca. $2660 \mathrm{Ma}$. The first regional compression event 
resulted in north-trending folds which are now largely overprinted by 2 or more E-W oriented folding and faulting events that now dominate the structural grain of the belt. Regional structures such as the PorcupineDestor and Larder Lake-Cadillac faults, show evidence for early truncation of strata (without accompanying development of tectonic fabric) suggesting their inception as synvolcanic growth faults in a rift environment, and later reactivated as ductile faults with both dip- and strike-slip displacements associated with the E-W regional folding and faulting events. The late movement was also genetically associated with the localization of the major gold deposits (Ayer et al 2002b). In the MGB, the presence of tectonic fabric in the cycle 4 rocks indicates that three major compressive structural events occurred between 2682 and $2671 \mathrm{Ma}$ (Corfu and Sage 1992). $F_{1}$ corresponds to the development of a belt-scale recumbent nappe fold that was imbricated and refolded during $F_{2}$. The eastnortheast trending shear zones are associated with $\mathrm{D}_{3}$, have a dominantly dextral strike-slip sense of motion and are hosts to gold mineralization.

\section{LAMPROPHYRE PETROGENESIS}

Archean lamprophyres are a common but volumetrically minor rock type in the Superior Province. The dikes display a preferred association with major structures. Field relations consistently indicate a late- to postkinematic timing for lamprophyre dike emplacement and a common association with other late Archean alkalic rock types. The dikes are among the youngest members of the alkalic suite in a given area. The late- to postkinematic emplacement of lamprophyres and associated rock types indicates that the origin of the alkalic suite was specifically related to those accretionary processes. A wide range of petrographic and mineralogical features that indicate crystal fractionation generally occurred in conjunction with the mixing of variably evolved batches of lamprophyric magma.

Major element compositions of the Archean lamprophyres confirm the similarity of the older dikes with younger shoshonitic examples. Weakly altered dikes typically have contents of $\mathrm{SiO}_{2}$ (47-51 wt.\%), $\mathrm{TiO}_{2}$ (0.5-1.4 wt. \%), and $\mathrm{P}_{2} \mathrm{O}_{5}(0.36-1.58$ wt.\%) and $\mathrm{K}_{2} \mathrm{O} / \mathrm{Na}_{2} \mathrm{O}$ ratios $(0.36-1.58 \%)$ similar to Phanerozoic lamprophyres. Weakly altered dikes are also characterized by extreme enrichments of the lithophile elements $\mathrm{K}, \mathrm{Rb}, \mathrm{Ba}, \mathrm{Cs}, \mathrm{Th}, \mathrm{U}$, and light rare earths and, in primitive lamprophyres, enhanced abundances of $\mathrm{Cr}$ (650-960 ppm), Co (37-42 ppm), Ni (264-358 ppm) and Sc (22-33). The major and trace element abundances of weakly altered dikes collectively indicate that the lamprophyres were derived from a depleted mantle source, variably enriched in LILE and LREE.

The $\mathrm{O}$ isotope composition of the Abitibi lamprophyre magma was close to the 6.3 per mil value obtained from a clinopyroxene mineral separate. This value is comparable to that of Colima Graben minette clinopyroxenes and provides further evidence that Archean and Phanerozoic shoshonitic lamprophyres were derived from similar mantle sources. Sm-Nd isotopic compositions of Superior Province lamprophyres are comparable to those of other members of the late alkalic suite $\left(\varepsilon_{\mathrm{Nd}}=\sim 0.5\right.$ to $\left.\sim 2.0\right)$. Lamprophyre compositions in the Abitibi Subprovince, for example, encompass slightly lower $\varepsilon_{\mathrm{Nd}}$ values than pre-kinematic mantle derived rock types of the same region. Collectively, the Sm-Nd compositions of alkalic rock types in the Superior Province may be explained by enrichment events incorporating old clastic material or fluids derived from such material. The relatively high $\partial^{18} \mathrm{O}$ values of Archean lamprophyres are consistent with a clastic sedimentary component in their mantle source.

Diamonds have been recovered from hypabyssal and fragmental lamprophyre facies from two districts in the Wawa and Abitibi subprovinces (Williams, 2002). Diamond-associated lamprophyres from these districts are distinguished from other Archean lamprophyres by the presence of rounded to sub-angular ultramafic xenoliths that are up to $1 \mathrm{~m}$ in diameter (Sage, 2000). In addition, non-diamondiferous lamprophyres typically occur as dykes whereas the more violent emplacement of the diamondiferous lamprophyres have fragmental facies. More than 20,000 diamonds have been recovered, with over $95 \%$ being microdiamonds. The diamonds are clear, white, yellow, pink and green and occur as fragments, octahedroids and twinned polytetrahedroids (Sage, 2000). Grade estimates range from 0.2 to 1 carat per tonne.

The diamond-associated lamprophyres tend to be more primitive than other Superior Province examples and define distinct chemical trends that only partially overlap trends for other Archean lamprophyres (Fig. 3; Williams, 2002). This characteristic is a consequence of contamination of the diamondiferous lamprophyre parent magmas with a primitive material compositionally similar to komatiite, which may have been diamond bearing. The compositions of ultramafic xenoliths found in some diamond-bearing dikes indicates that these inclusions are probably not the komatiitic contaminant. 

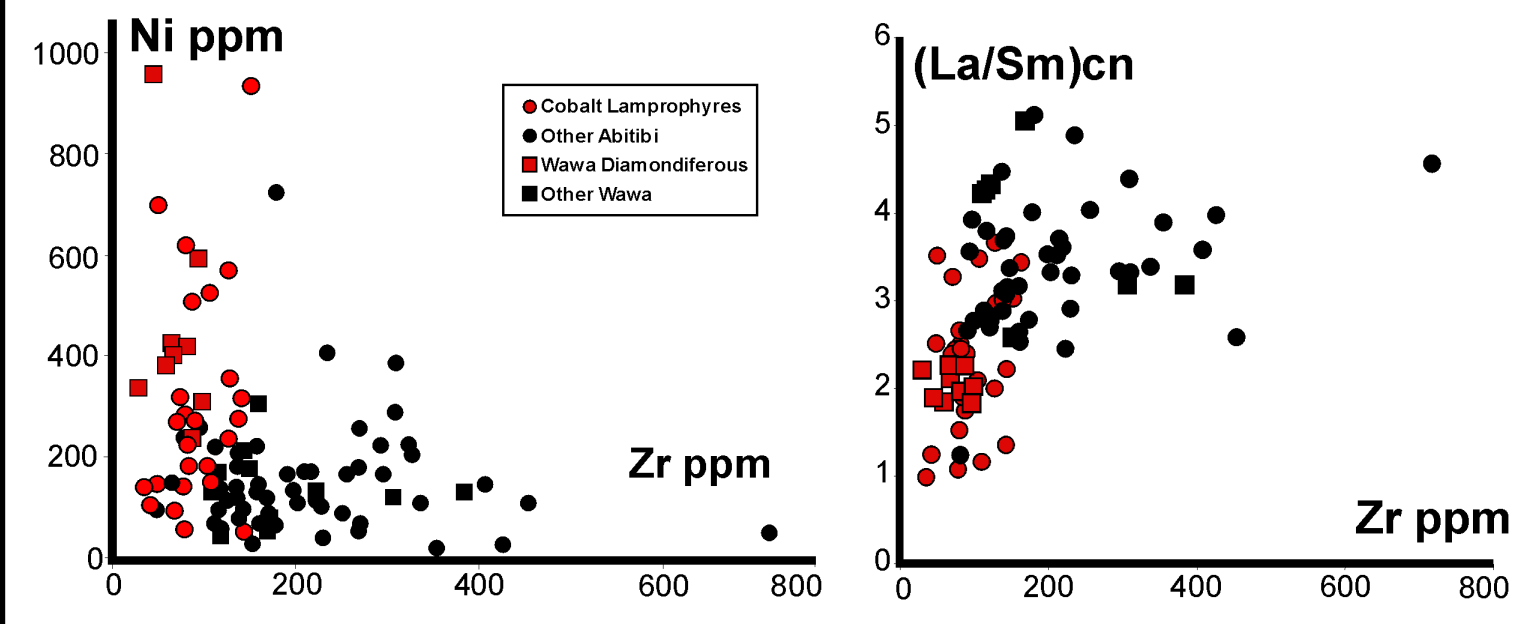

Figure 3: Trace element plots for diamondiferous (red symbols) and non-diamondiferous (black symbols) lamprophyres of the Abitibi and Wawe subprovince (Williams, 2002). Diamondiferous lamprophyres extend to more primitive

\section{DISCUSSION AND CONCLUSIONS}

Chemical compositions, petrography and field relations among the diamond-associated lamprophyre facies rocks indicate they are all derived from similar magmas that have been variably contaminated by an (ultra)mafic component. This is an important constraint because shoshonitic lamprophyres are generally derived from relatively shallow upper mantle sources, typically from the spinel lherzolite field at depths of less than $80 \mathrm{~km}$. As a result, the parental magmas are usually generated above the diamond stability field. In addition, some evidence suggests that the deep mantle keel of the southern Abitibi subprovince, and probably the Wawa subprovince, was not in place at $2764 \mathrm{Ma}$, which is the approximate time of lamprophyre emplacement. In fact, the lamprophyric magmas themselves were derived from subduction-modified asthenosphere that remained beneath the greenstone belts (Wyman and Kerrich, 2002). These observations suggest that either the diamonds were transported from greater depths and then sampled by the lamprophyric magmas, or they grew metastably above the diamond stability field.

Meta-stable growth models have been applied to postArchean diamonds found in crustal rocks subject to anisotropic stress in a tectonic mélange zone (Kazakhstan: Dobrzhinetskaya et al., 1994). The tectonic and incompatible element enriched compositions with less fractionation of the light rare earth elements. However, individual diamond-bearing samples occur in the region of overlap on these plots. setting of the Wawa and Cobalt diamond occurrences in the southern Superior Province resembles the regional setting associated with crustal diamonds in Kazakhstan (Williams, 2002). However, these crustal occurrences are generally restricted to microdiamonds of less than $100 \mu \mathrm{m}$ width (Haggerty, 1999), whereas the Archean localities contain numerous macrodiamonds. In addition, the Canadian diamonds have clearly been transported from greater depths in rapidly ascending, volatile-rich, magmas.

The probable absence of a durable and thick cratonic root at $2674 \mathrm{Ma}$ indicates a variant of the subduction diamond models as applied to Phanerozoic SE Australia may be appropriate. Griffin et al (2000) propose that diamonds formed near the top of a subducting slab and were entrained in unidentified slab-penetrating magmas (Figure 4). The shoshonitic or sanukitoid magmas responsible for late Archean lamprophyres and related rock types are derived from subduction-modified mantle wedge and therefore cannot be directly analogous to magma type invoked by Griffin et al (2000). If the slabbreaching magma in this model is represented by the ultramafic contaminant identified in the dikes then a magma mixing event above a (fossil) subducted slab is required. The scenario requires that the mixing event immediately predated ascent of diamond-bearing 
shoshonitic magmas in order that the diamonds be preserved, given the syn-tectonic context of the southern Superior Province lamprophyres. More plausibly, the diamonds formed at relatively shallow depths $(80-100$ $\mathrm{km}$ ) in a subduction-generated low temperature window located in subducted or underplated oceanic crust (e.g., Barron et al. 1996). Assent of lamprophryric magmas immediately following subduction allowed for entrainment of the diamonds during late Archean orogeny.

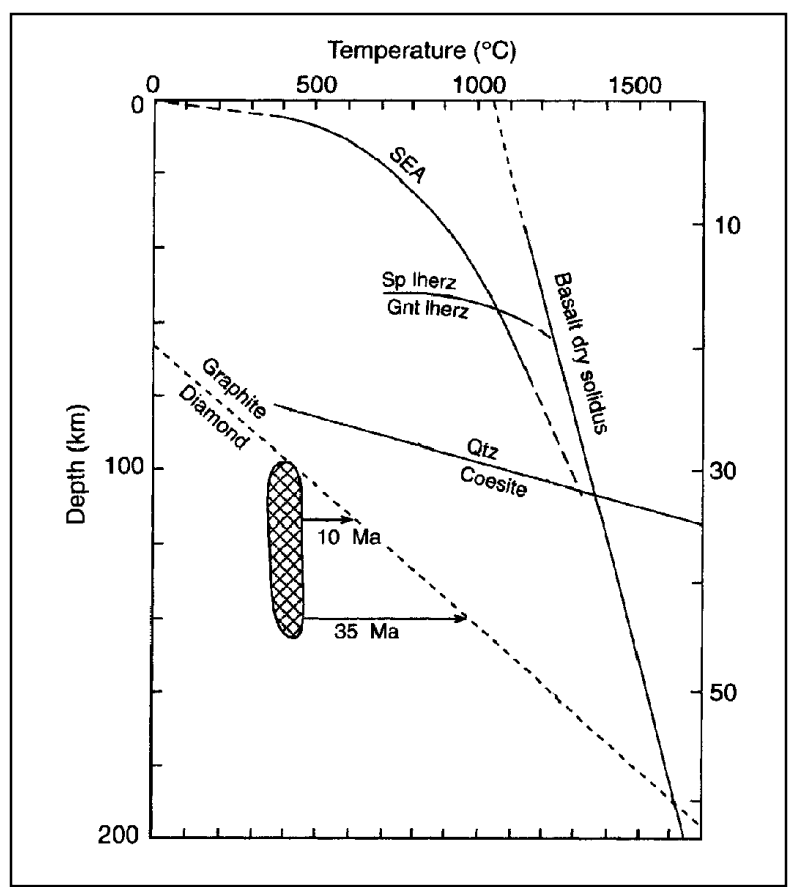

Figure 4: The graphite-diamond and quartz-coesite stability fields and the temp-depth range of Phanerozoic subducted slab (hatched). $10 \mathrm{Ma}$ and $35 \mathrm{Ma}$ lines indicate equilibrium times for the slab to enter the graphite field. SEA = Southeastern Australia geotherm. Simplified from Griffin et al. 2002.

\section{REFERENCES}

Ayer, J., Amelin, Y., Corfu, F., Kamo, S., Ketchum, J., Kwok, K., Trowell, N., 2002a. Evolution of the southern Abitibi greenstone belt based on U-Pb geochronology: autochthonous volcanic construction followed by plutonism, regional deformation and sedimentation; Precambrian Res. 115, 63-95.

Ayer, J.A., Ketchum, J.W.F., Trowell, N.F., 2002b. New geochronological and $\mathrm{Nd}$ isotopic results from the Abitibi Greenstone belt, with emphasis on timing and tectonic implications of Late Archean sedimentation and volcanism. Summary of Field work and Other
Activities, Ontario Geological Survey, Open File Report 6100, p5-1 to 5-16.

Barron, L.M., Lishmunwg, R., Oakes, M., Barron, B.J., Sutherland, F. L., 1996. Subduction model for the origin of some diamonds in the Phanerozoic of eastern New South Wales. Aust. J. Earth Sci. 43, 257-267.

Corfu, F., Sage, R.P., 1992. U-Pb age constraints for deposition of clastic metasedimentary rocks and late-tectonic plutonism, Michipicoten Belt, superior Province. Can. J. Earth Sci. 29, 1640-1651.

Dobrzhinetskaya, L.F., Braun, T.V., Sheshkel, G.G., Podkuiko, Y. A., 1994. Geology and structure of diamond-bearing rocks of the Kokchetav massif (Kazakhstan). Tectonophysics 233, 292-313.

Griffin, W.L., O’Reilly, S.Y., Davies R.M., 2000. Subductionrelated diamond deposits? Constraints, possibilities and new data from eastern Australia. Reviews in Economic Geology 11, 291-310.

Haggerty, S.E., 1986. Diamond genesis in a multiplyconstrained model. Nature 320, 34-38.

Jackson, S.L., Fyon, A.J., Corfu, F., 1994. Review of Archean supracrustal assemblages of the southern Abitibi greenstone belt in Ontario, Canada: products of microplate interaction within a large-scale platetectonic setting, Precambrian Res. 65, .183-205.

Sage, R.P., Lightfoot, P.C., Doherty, W., 1996. Bimodal cyclical Archean basalts and rhyolites from the Michipicoten (Wawa) greenstone belt, Ontario: geochemical evidence for magma contributions from the athenospheric mantle and ancient continental lithosphere near the southern margin of the Superior Province. Precambrian Res. 76, 119-153.

Williams, F., 2002. Diamonds in Late Archean Calc-alkaline Lamprophyres Ontario, Canada: Origins and Implications. Unpub. Honours Thesis, University of Sydney.

Wyman, D.A., Kerrich, R., 1993. Archean shoshonitic lamprophyres of the Abitibi subprovince, Canada: petrogenesis, age, and tectonic setting. J. Petrol. 34, 1067-1109.

Wyman D. A. \& Kerrich R. 2002. Formation of Archean continental lithospheric roots: The role of mantle plumes. Geology 30, 543-546.

Contact: J. Ayer, Ontario Geological Survey, 933 Ramsey Lake Road, Sudbury, ON, Canada, P3E 6B5

E-mail: john.ayer@mdn.gov.on.ca 